\title{
POLITYCZNE I KULTUROWE KONSEKWENCJE SPORÓW ARIAŃSKICH W IV WIEKU
}

Celem niniejszego opracowania jest próba syntetycznego określenia cywilnego wymiaru kwestii ariańskiej w Cesarstwie Rzymskim w IV wieku. W oparciu o analizę dokumentów teologicznych i historycznych z tamtego okresu, chcę ukazać oddziaływanie arianizmu na kształtowanie się postaw społeczno-politycznych i kulturowych. Ze względu na rozległość zagadnienia w niniejszym artykule zaakcentuję dwie kwestie zasadnicze. Po pierwsze chcę opisać sposób angażowania się cesarzy z dynastii konstantyjskiej i walentyniańskiej w kontrowersję ariańską. Po drugie spróbuję określić, dlaczego plemiona germańskie masowo przyjmowały arianizm w IV wieku. Status quaestionis poruszanych zagadnień jest dobrze udokumentowany w literaturze zagranicznej ${ }^{1}$. W literaturze w języku polskim

1 Por. Università degli Studi di Firenze. Seminario di Filologia Germanica, Studi sulla civiltà dei Goti, Firenze 1971; M. Simonetti, La crisi ariana nel IV secolo, Roma 1975; B. Scardigli, P. Scardigli, I rapporti fra Goti e Romani nel III e IV secolo, „Romanobarbarica” 1 (1976), s. 260-295; M. Simonetti, L'arianesimo di Ulfila, „Romanobarbarica” 1 (1976), s. 297-323; M. Pavan, Sant'Ambrogio e il problema dei barbari, „Romanobarbarica” 3 (1978), s. 167-187; Evangelizzazione dell'occidente dal III all'VIII secolo. Lingua e linguaggi. Dibattito teologico. Saggi racolti ed editi, red. I. Mazzini i L. Bacci, Roma 2001 (Biblioteca di Cultura Romanobarbarica, 5); B. Luiselli, La formazione della cultura europea occidentale, Roma 2003; Fonti per la storia della cristia- 
istnieją klasyczne analizy historyczne arianizmu ${ }^{2}$ oraz fragmentaryczne wzmianki na marginesie innych rozważań ${ }^{3}$. Brakuje jednak syntezy powyższych zagadnień, pisanej z uwzględnieniem najnowszych ujęć arianizmu. Odnoszę się tutaj szczególnie do rezultatów badań Henryka Pietrasa i Bruno Luiselliego.

\section{Interwencje cesarzy w kwestie wiary chrześcijańskiej}

W Kościele istniała już od II wieku instytucja synodów lokalnych ${ }^{4}$. Konstantyn Wielki, analogicznie do ściśle cesarskiej instytucji sacrum consistorium (przekształconej przez tegoż władcę z wcześniejszego consilium principis ${ }^{5}$ ) powołał natomiast w 325 roku zależną od siebie radę kościelną. Owo cesarskie concilium stanowiło w zamyśle Konstantyna najprawdopodobniej zespół kościelnych ekspertów, a tym, kto ostatecznie podejmował decyzję, był cesarz. O takim

nizzazione dei Germani (secoli III-VIII), red. B. Luiselli et al., Roma 2007 (Biblioteca di Cultura Romanobarbarica, 9).

2 D. Spychała, Cesarze rzymscy a arianizm: od Konstantyna Wielkiego do Teodozjusza Wielkiego (312-395), Poznań 2007; S. Bralewski, Cesarz Konstantyn I Wielki wobec kontrowersji ariańskiej, Poznań 2009.

3 J. Gliściński, Wspótistotny Ojcu, Łódź 1992, s. 142-148; P. Heather, Upadek Cesarstwa Rzymskiego, tłum. J. Szczepański, Poznań 2006, s. 96-101; B. Dumézil, Chrześcijańskie korzenie Europy. Konwersja i wolność w królestwach barbarzyńskich od V do VIII wieku, tłum. P. Rak, Kęty 2008, s. 270-280; D. Kasprzak, Konwersja na chrześcijaństwo plemion germańskich od IV do IX wieku, „Roczniki Historii Kościoła” 2/57 (2010), s. 19-55.

$4 \quad$ K. Schatz (Sobory powszechne. Punkty zwrotne w historii Kościoła, tłum. J. Zakrzewski, Kraków 2001, s. 15), uważa, że pierwszym poświadczonym synodem kościelnym był synod z Rzymu zwołany ok. 195 roku w związku ze sporem o datę obchodzenia uroczystości Zmartwychwstania. Jednak synodów wcześniejszych w II wieku, których dokumentacja jest mniej pewna, mogło być kilka: Synod na Sycylii przeciwko gnostykowi Herakleonowi; Synod w Rzymie przeciwko adopcjoniście Teodorowi z Bizancjum; Synod w Pergamonie (ok. 152) przeciwko gnostykowi Colorbasusowi; Synod w Rzymie (ok. 154/155) o dacie Wielkanocy; Synod w Hierapolis (ok. 150170) przeciwko montanistom; Synod w Azji Mniejszej (ok. 189-199) o dacie Wielkanocy. Por. Dokumenty synodów od 50 do 381 roku, red. A. Baron, H. Pietras, Kraków 2006, s. 2-2* (Źródła Myśli Teologicznej, 37 [dalej publikacje z tej serii cytowane jako: ŹMT i numer tomu]).

5 Por. J. Crook, Consilium principis, imperial councils and counsellors from Augustus to Diocletian, New York 1975. 
pojmowaniu tego novum organizacyjnego świadczy, zdaniem Klausa Schatza, miejsce obrad tej rady, czyli letni pałac w cesarskiej miejscowości wypoczynkowej - Nicei, zamiast któregoś z centralnych ośrodków miejskich antycznego Kościoła (czyli: Efezu, Antiochii, Aleksandrii, Kartaginy, Rzymu czy Arlesu) ${ }^{6}$.

Co więcej, cesarz Konstantyn Wielki także w sprawach chrześcijańskich działał jako najwyższy pontyfik. Z urzędu jako pontifex maximus ustanowił w 321 roku niedzielę dniem wolnym od pracy (por. Codex Justinianus III, 12, 2), ułożył modlitwę do odmawiania przez legionistów (por. Vita Constantini IV, 19) ${ }^{7}$ i miał obowiązek przechowywania świętych formuł wszystkich religii i czuwania, aby wierni się do nich stosowali. Jako że w cesarskich Pontyfikałach nie było dotąd tekstów chrześcijańskich, cesarz jako pontifex maximus nie mógł czuwać nad prawidłowością chrześcijańskiego kultu. Każdy Kościół lokalny posiadał własne credo chrzcielne, lecz cesarz potrzebował credo bardziej ogólnego. Cesarz nie domagał się od chrześcijan ich inicjacyjnych formuł modlitewnych (jak w przypadku innych religii), ale tekstu wyznania wiary. Zdaniem H. Pietrasa stało się tak prawdopodobnie dlatego, że credo stanowiło tekst używany w czasie inicjacji chrześcijańskiej; cesarz mógł je zatem uznać za równorzędne $\mathrm{z}$ formułami inicjacyjnymi ${ }^{8}$. Na podstawie powyższego rozumowania dotyczącego obowiązków cesarza jako pontifex maximus oraz nieudanej misji biskupa Hozjusza z Kordoby na Wschodzie (niezadowolenie z antiocheńskiego wyznania wiary z 324 roku), H. Pietras postawił hipotezę, że:

Konstantyn zaprosił biskupów do Nicei na uroczystość otwarcia jubileuszowego roku dwudziestolecia swego panowania. Przy tej podniosłej okazji zamierzał ogłosić uroczyście pojednanie wszystkich zwaśnionych stron, kalendarz paschalny oraz podstawową formułę wiary chrześcijańskiej. Że nie arianizm był powodem zwołania soboru, zauważył już Angelo di Berardino w 1990 roku, ale trzeba przyznać, ze uczynił to dość nieśmiało.

6 Por. K. Schatz, Sobory powszechne..., dz. cyt., s. 26.

7 Por. H. Pietras, Sobór nicejski (325). Kontekst religijny i polityczny, dokumenty, komentarze, Kraków 2013, s. 123-124.

8 Por. H. Pietras, Sobór nicejski (325)..., dz. cyt., s. 128-129.

$9 \quad$ H. Pietras, Sobór nicejski (325)..., dz. cyt., s. 137; Por. A. di Berardino, L'imperatore Costantino e la celebrazione della Pasqua, [w:] G. Bonamente, F. Fusco, Costantino il Grande dall'antichità all'umanesimo, t. 1, Macerata 1992, s. 368. 
Zatem Konstantyn Wielki zwoła1 ${ }^{10}$, zainaugurował ${ }^{11}$ i praktycznie, choć nieformalnie, przewodniczył obradom consilium w 325 roku w Nicei ${ }^{12}$. Cesarz kierował obradami spotkania i miał bezpośredni wpływ na jego decyzje ${ }^{13}$. Do śmierci cesarza Konstantyna I (zm. 337) credo nicejskie było co prawda oficjalną formułą wiary chrześcijańskiej $^{14}$, prawdopodobnie wpisaną do cesarskiego Liber pontificalis ${ }^{15}$, jednak nieużywaną w Kościele ani na Wschodzie ${ }^{16}$, ani na Zachodzie ${ }^{17}$. Natomiast w Kościele od 325 roku przyjęła się bardzo dobrze instytucja cesarskiego consilum, znana w językach słowiańskich jako sobór.

Pragnę zwrócić uwagę na inny aspekt działalności polityczno-eklezjalnej cesarza Konstantyna Wielkiego. Prawdopodobnie zmusił on 17 biskupów do podpisania wyznania wiary, grożąc im wygnaniem ze stolic biskupich. Tylko dwóch z nich (Secundus z Ptolemaidy i Teonas z Marmaryki) nie głosowało na "tak” i dlatego zostali usunięci

10 Por. Euzebiusz z Cezarei, Życie Konstantyna 3, 6, wstęp, tłum., przypisy T. Wnętrzak, Kraków 2007, s. 171-172 (ŹMT 44).

11 Por. Euzebiusz z Cezarei, Życie Konstantyna 3, 12, [w:] ŹMT 44, s. 175.

12 K. Schatz, Sobory powszechne..., dz. cyt., s. 28, zaznacza, że nie posiadamy żadnych akt z cesarskiego consilium z 325 roku; notatki z Vita Constantini Euzebiusza oraz te Atanazego z Aleksandrii musimy rozpatrywać bardzo krytycznie, tym bardziej wzmianki o soborze u późniejszych historyków kościelnych, jak u Sokratesa Scholastyka. Jeśli zatem przyjąć założenie, że Konstantyn traktował consilium jako swoją radę, to wolno przypuszczać, że to on przewodniczył zwołanemu przez siebie gremium. Natomiast Hozjusz z Kordoby kierował radą jako oficjalny przedstawiciel cesarza, ponieważ na wszystkich listach imię Hozjusza znajduje się na pierwszym miejscu, a po nim dopiero są wymieniani dwaj przedstawiciele biskupa Rzymu.

13 Por. Euzebiusz z Cezarei, Życie Konstantyna 3, 13, [w:] ŹMT 44, s. 176; Sokrates Scholastyk, Historia ecclesiastica 1, 8 (Patrologia Graeca, ed. J. P. Migne, Paris 1857-1866, t. 67 [dalej publikacje z tej serii cytowane jako: PG i numer tomu]); Sozomen, Historia ecclesiastica 1, 17, ed. J. Bidez, G. Ch. Hansen, Berlin 1960 (Die Griechischen Christlichen Schriftsteller [dalej: GCS], 50); Rufin z Akwilei, Historia ecclesiastica 1, 2, ed. M. Simonetti, Aquileia 2000, s. 188 (Scrittori della Chesa di Aquileia [dalej: SCA], V/20).

14 Por. S. Bralewski, Cesarz Konstantyn I Wielki wobec kontrowersji ariańskiej..., dz. cyt., s. 28.

15 Por. H. Pietras, Sobór Nicejski (325)..., dz. cyt., s. 213.

16 Por. H. Pietras, Sobór Nicejski (325)..., dz. cyt., s. 180; autor odnośnie do credo nicejskiego wykazał, że „nie ma żadnego śladu, by ktokolwiek, kiedykolwiek i do czegokolwiek go używał w Kościele".

17 Por. tekst w tym tomie studiów: D. Kasprzak, Recepcja credo nicejskiego w nauczaniu synodalnym Kościoła zachodniego IV wieku. 
z urzędu i skazani przez cesarza na wygnanie ${ }^{18}$. Cesarz uwiarygodnił zatem kościelne pozbawienie urzędów i wykluczenie ze stanu duchownego zwolenników Ariusza. Tego typu praktyka politycznego wymuszania na biskupach czy prezbiterach określonej opinii podzielanej przez władcę oraz sankcjonowania przez władzę cesarską ustaleń kościelnych stała się swoistą normą w Cesarstwie Rzymskim po 325 roku. Decyzja cesarza nie wynikała z wychowania chrześcijańskiego czy jego osobistej wiary, ale była efektem pragmatycznego podejścia Konstantyna do zachowania jedności religijnej chrześcijaństwa. Brak podpisu biskupów pod cesarskim aktem wiary z Nicei z 325 roku był traktowany jako nieposłuszeństwo wobec cesarza i jednocześnie najwyższego pontyfika.

Jeśli legislacja Konstantyna Wielkiego od roku 313 faworyzowała chrześcijaństwo ${ }^{19}$, to stała się ona otwarcie prochrześcijańska od

18 List synodu w Nicei do Egipcjan 5 [w:] Dokumenty Soborów Powszechnych, tekst grecki, łaciński, polski, red. A. Baron, H. Pietras, t. 1, 325-787, Kraków 2001, s. 49 (ŹMT 24): „Jego [tj. Ariusza - przyp. D. K.] bezbożność miała tak wielką siłę oddziaływania, że przyłączyli się do niego Theonas z Marmaryki i Secundus z Ptolemais - obaj otrzymali ten sam wyrok [co Ariusz - przyp. D. K.]". Obaj wymienieni biskupi jako stronnicy Ariusza zostali też potępieni wcześniej, w 323 roku, na antyariańskim synodzie w Aleksandrii, por. List Aleksandra 6 [w:] ŹMT 37, s. 79*: „Odstępcami są Ariusz, Achileus, Aeitales i Karpones, ponadto drugi Ariusz, Sarmates, byli prezbiterzy, oraz byli diakoni Euzojusz, Lukiusz, Juliusz, Menas, Helladios, Gajusz, a wraz z nimi Sekundus i Teonas, uważani kiedyś za biskupów".

19 Spośród bardziej znaczących ustaw cesarskich należy wymienić edykt z kwietnia 313 roku o restytucji dóbr Kościoła zagarniętych wcześniej przez państwo (Euzebiusz z Cezarei, Historia ecclesiastica 10, 5, 15-17, red. E. Schwartz, T. Mommsen, Berlin 1908 (GCS 9/2, s. 887)); reskrypt z kwietnia 313 roku przyznający pomoc pieniężną Kościołowi w Kartaginie (Euzebiusz z Cezarei, Historia ecclesiastica 10, 6, 1-5, s. 890); reskrypt z 31 grudnia 313 roku dotyczący wyłączenia biskupów z pełnienia jakichkolwiek urzędów publicznych (Euzebiusz z Cezarei, Historia ecclesiastica 10, 7, 1-2, dz. cyt., s. 891); edykt z 18 października 315 roku do prefekta pretorium o dyrektywach chroniących konwertytów z judaizmu na chrześcijaństwo przeciwko konwertytom chrześcijaństwa na judaizm (Codex Theodosianus 16, 8, 1, ed. P. Krueger, T. Mommsen, Berlin 1905, s. 887); ustawa ogólna z 23 czerwca 318 roku dotycząca przyznania biskupom „audientia episcopalis” (Codex Theodosianus 1, 27, 1, dz. cyt., s. 62); ustawa ogólna z 21 października 319 roku o wyłączeniu duchowieństwa chrześcijańskiego z obowiązków cywilnych (Codex Theodosianus 16, 2, 2, dz. cyt., s. 835); ustawa ogólna z 18 lipca 320 roku zabraniająca dekurionom i ich potomkom wstępowania w szeregi duchowieństwa chrześcijańskiego celem ucieczki od obowiązków względem państwa (Codex Theodosianus 16, 2, 3, dz. cyt., s. 835-836); ustawa ogólna z 18 kwietnia 321 roku przyznająca kapłanom chrześcijańskim prawo wyzwalania 
324 roku, kiedy cesarz stał się jedynym augustem Imperium Romanum. Spośród ważnych decyzji Konstantyna popierających chrześcijaństwo nicejskie należy wymienić prawo do cursus publicus przyznane biskupom katolickim, prawo o immunitecie kościelnym i państwowe potwierdzenie ważności cywilnej sentencji wydawanych przez biskupa ${ }^{20}$. Konstantyn, wydając powyższe normy prawne, chciał stworzyć system pokojowej koegzystencji w oparciu o równorzędną i wzajemną współpracę między państwem a Kościołem, którą dobrze oddawał termin synallelia ${ }^{21}$.

Konstantyn, respektując autonomię kościelną dotyczącą legisla-

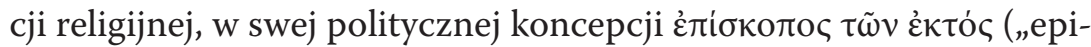
scopus rerum externarum") zwracał się przeciwko schizmom czy herezjom niszczącym jedność chrześcijaństwa ${ }^{22}$. Wychodząc od tej

ich niewolników bez udziału świadków przewidzianych przez prawo (Codex Theodosianus 4, 7, 1, dz. cyt., s. 179); ustawa ogólna z 3 lipca 321 roku pozwalająca na wyzwolenie niewolników w niedzielę (Codex Theodosianus 2, 8, 1, dz. cyt., s. 87); ustawa ogólna z 3 lipca 321 roku uznająca ważność prawną aktów spadkowych na korzyść instytucji Kościoła katolickiego (Codex Theodosianus 16, 2, 4, dz. cyt., s. 836); prawo ogólne z 25 grudnia 323 roku przeciwko przymuszaniu katolików do składania ofiar kultu niechrześcijańskiego (Codex Theodosianus 16, 2, 5, dz. cyt., s. 836); Por. B. Biondi, Il diritto romano cristiano, vol. I, Orientamento religioso della legislazione, Milano 1952, s. 115-230.

20 Na temat cursus publicus przyznanego biskupom zob. Euzebiusz z Cezarei, Historia ecclesiastica 10, 5, 21-24, dz. cyt., s. 888-890; por. też: H. M. Jones, The later Roman Empire. 284-602. A social economic and administrative survey, vol. II, ed. B. Blackwell, Oxford 1964, s. 830-832; reskrypt cesarski z dnia 5 maja 333 roku o powszechności jurysdykcji biskupów i nieodwoływalności od ich sentencji w materii cywilnej por. Constitutionibus Sirmondianis 1, ed. P. Krueger, Th. Mommsen, Berlin 1905, s. 907-908.

21 Por. A. Barzanò, Il Cristianesimo nelle leggi di Roma Imperiale, Milano 1996, s. 64.

22 Np. edykt cesarski z 31 października 313 roku przeciwko przemocy ze strony donatystów powodującej szkody materialne duchowieństwa katolickiego w Afryce (Codex Theodosianus 16, 2, 1, dz. cyt., s. 835); ustawa ogólna z dnia 1 sierpnia 326 roku wykluczająca heretyków i schizmatyków od zwolnień podatkowych przyznanych katolikom (Codex Theodosianus 16, 5, 1, dz. cyt., s. 855). Por. J. A. Straub, Kaiser Konstantin

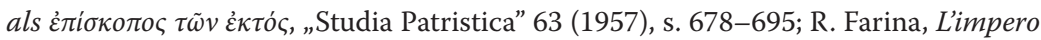
e l'imperatore cristiano in Eusebio di Cesarea. La prima teologia politica del cristianesimo, Zürich 1966, s. 236-248 (Biblioteca Teologica Salesiana. Fontes, 2); K. M. Setton, Christian attitude towards the Emperor in the fourth century especially as shown in addresses to the Emperor, New York 1967 (Studies in History, Economics and Public Law, 482); E. Dal Covolo, Il „capovolgimento” dei rapporti tra la Chiesa e l'impero, [w:] Chiesa e impero. Da Augusto a Giustiniano, ed. E. Dal Covolo, R. Uglione, Roma 
zasady zachowania porządku religijnego w cesarstwie, Konstantyn zapoczątkował zwyczaj ingerowania cesarzy chrześcijańskich w problemy doktrynalne. Sam Konstantyn ujawnił ten sposób postępowania przede wszystkim $\mathrm{w}$ polityce przeciwko donatystom oraz podczas consilum cesarskiego w Nicei w $325 \mathrm{roku}^{23}$.

Następcy Konstantyna byli przede wszystkim ludźmi działającymi na rzecz państwa, niezależnie od wiary, jaką wyznawali. Cesarze części zachodniej Imperium Romanum Konstantyn II (317340) i Konstans I (320-350) kontynuowali politykę pronicejską ${ }^{24}$. Natomiast wschodni cesarz Konstancjusz II (317-361) był filoarianinem, wpływając przez to na decyzje synodów kościelnych w Arles (353), Mediolanie (355) i Béziers (356). W wyniku jego decyzji

2001, s. 199-208 (Biblioteca di Scienze Religiose, 170); G. Bonamente, La „svolta costantiniana", [w:] Chiesa e impero..., dz. cyt., s. 145-170; A. Baldini, Il dibattito contemporaneo sulla conversione di Costantino, „Salesianum” 67 (2005), s. 701-735.

23 List cesarski z 10 maja 313 roku do papieża Milcjadesa o zwołanie synodu w kwestii donatyzmu (Euzebiusz z Cezarei, Historia ecclesiastica, 10, 5, 18-20, dz. cyt., s. 887-888). Por. R. Rémondon, La crisi dell'Impero Romano. Da Marco Aurelio ad Anastasio, Milano 1975, s. 115; S. Mazzarino, L'Impero romano, vol. II, Roma-Bari 1996, s. 661-666; M. Simonetti, La crisi ariana nel IV secolo..., dz. cyt., s. 35-41.

24 W prawodawstwie dynastii Konstantynów generalnie przeważa prąd antyżydowski i antypogański: zob. ustawa Konstansa I z 13 sierpnia 339 roku przeciwko zawieraniu małżeństw żydowsko-chrześcijańskich (Codex Theodosianus 16, 8, 6, dz.cyt., s. 888); edykt Konstansa I przeciwko prawu do posiadania i obrzezywania niewolników nieżydowskich, w szczególności jeśli są chrześcijanami (Codex Theodosianus 16, 9, dz. cyt., s. 896); prawo wydane przez Konstansa I dnia 3 lipca 352 (lub 353) dotyczące konfiskaty dóbr chrześcijan dokonujących konwersji na judaizm (Codex Theodosianus 16, 8, 7, dz. cyt., s. 888); edykt Konstansa I z 341 roku zakazujący dokonywania ofiar w rycie pogańskim (Codex Theodosianus 16, 10, 2, dz. cyt., s. 897); prawo cesarskie promulgowane przez Konstansa I i Konstancjusza II z dnia 1 listopada 346 (342) roku o ochronie integralności budynków kościelnych znajdujących się poza murami miejskimi (Codex Theodosianus 16, 10, 3, dz. cyt., s. 898); edykt Konstancjusza II z dnia 23 listopada 352 roku zabraniający poganom celebrowania ofiar wieczornych oraz edykt z 19 lutego 356 roku nakładający karę śmierci na osoby sprawujące akty związane z kultem pogańskim (Codex Theodosianus 16, 10, 6, dz. cyt., s. 898); prawo Konstancjusza II z dnia 4 grudnia 357 roku skierowane przeciwko praktykującym magię (Codex Theodosianus 9, 16, 5, dz. cyt., s. 461); prawo Konstancjusza II z dnia 25 stycznia 357 przeciwko praktykom magicznym (Codex Theodosianus 9, 16, 4, dz. cyt., s. 461). Por.: B. Biondi, Il diritto romano cristiano, vol. I, Orientamento religioso..., dz. cyt.; L. De Giovanni, Il Libro XVI del Codice Teodosiano. Alle origini della codificazione in tema di rapporti Chiesa-Stato, Napoli 1985; D. Gemmiti, La Chiesa privilegiata nel Codice Teodosiano. Vescovo, clero e monaci: aspetti emblematici, Napoli-Roma 1991. 
zostali pozbawieniu urzędu biskupiego i skazani na wygnanie tacy biskupi pronicejscy jak Atanazy z Aleksandrii, Hilary z Poitiers, Dionizy z Mediolanu, Liberiusz z Rzymu i Hozjusz z Kordoby ${ }^{25}$. Konstancjusz II próbował podporządkować Kościół państwu rzymskie$\mathrm{mu}$, co było widoczne podczas zwołanego przezeń synodu w Sardyce w 343 roku, a szczególnie od 351 roku, kiedy został jedynym władcą cesarstwa. Znacząca wobec tych działań Konstancjusza II była wyraźna opozycja biskupów pronicejskich: Atanazego z Aleksandrii, Juliusza I z Rzymu, Liberiusza z Rzymu, Hilarego z Poitiers, Rodaniusza z Tuluzy, Hozjusza z Kordoby i Lucyferiusza z Cagliari. Pozwoliła ona na zachowanie autonomii wobec władzy świeckiej i nietraktowanie woli politycznej cesarza jako prawa obowiązującego w Kościele ${ }^{26}$.

Cesarz Walens (328-378), rządzący „pars Orientis Imperium Romanum" w swej polityce religijnej również był filoarianinem, kontynuował politykę interwencjonizmu państwowego w obszarze kościelnym ${ }^{27}$. Natomiast w „pars Occidentis Imperium Romanum”, pomimo próby restauracji pogaństwa za rządów Juliana Apostaty w latach 361-363, nastąpiło jednak odwołanie z wygnania biskupów pronicejskich, pozbawionych stolic biskupich przez proariańskiego Konstancjusza $\mathrm{II}^{28}$.

Wraz z objęciem rządów w 364 roku przez pronicejskiego cesarza Walentyniana I, dzięki korzystnej dla nicejczyków legislacji cesarskiej umocniła się pozycja Kościoła katolickiego na Zachodzie. Cesarz Walentynian I, przyjmując neutralną postawę laicus, specjalnie nie ingerował w sprawy dotyczące doktryny chrześcijańskiej ${ }^{29}$. Cesarz Gracjan, zostawszy w 375 roku władcą części zachodniej cesarstwa,

25 Por. W. Ceran, Konstancjusz II, [w:] Encyklopedia kultury bizantyńskiej, red. O. Jurewicz, Warszawa 2002, s. 269-270; D. Spychała, Cesarze rzymscy a arianizm..., dz. cyt., s. 52-55.

26 Por. K. Baus, Il divenire della Chiesa imperiale nellambito della politica religiosa dell'Impero, [w:] Storia della Chiesa, vol. II, red. H. Jedin, Milano 1983, s. 89-92.

27 Por. D. Spychała, Cesarze rzymscy a arianizm..., dz. cyt., s. 55-57.

28 Por. W. Ceran, Kościót wobec antychrześcijańskiej polityki cesarza Juliana Apostaty, Łódź 1980 (Acta Universitatis Lodziensis. Seria I, Nauki Humanistyczno-Społeczne. Folia Historica, 63); H. Rahner, Chiesa e struttura politica nel cristianesimo primitivo, Milano 1990, s. 80-81; S. Olszaniec, Julian Apostata jako reformator religijny, Kraków 1999.

29 Por. Sozomen, Historia ecclesiastica VI, dz. cyt.; por. J. Gaudemet, L'Église dans l'Empire Romain (IV-V siècles), Paris 1958, s. 12-13; D. Spychała, Cesarze rzymscy a arianizm..., dz. cyt., s. 61-62. 
próbował kontynuować politykę religijną rozpoczętą przez Walentyniana I, opartą na neutralności panującego wobec spraw wiary. Jednak pod wpływem Ambrożego, biskupa Mediolanu, ostatecznie poparł wyraźnie stronę nicejską ${ }^{30}$, zaczął promulgować prawa antypogańskie i wydał dekret skierowany przeciwko pryscylianistom ${ }^{31}$.

Uzurpator Magnus Maksymus, w przeciwieństwie do proariańskiej polityki cesarzowej Justyny, często sprzeciwiającej się biskupowi Ambrożemu z Mediolanu ${ }^{32}$, starał się działać na rzecz duchowieństwa nicejskiego. W wyniku jego decyzji po raz pierwszy w historii relacji państwo-Kościół doszło do skazania na śmierć chrześcijanina za herezję z wyroku władzy świeckiej. W 385 roku wydał on wyrok śmierci na Pryscyliana i jego towarzyszy za herezję w stosunku do chrześcijaństwa ortodoksyjnego (oskarżenia o manicheizm, niemoralność i praktykowanie magii). Egzekucji dokonano w Trewirze pomimo protestów biskupów pronicejskich ${ }^{33}$.

Wraz z przybyciem na Zachód w 388 roku cesarza Teodozjusza z jego oddziałami wojskowymi rozpoczął się kolejny znaczący etap w relacjach pomiędzy Kościołem a państwem. W swej polityce religijnej Teodozjusz I jako gorliwy katolik starał się osiągnąć jedność religijną cesarstwa w oparciu o wyznanie nicejskie. Na mocy edyktu Cunctos populos z 27 lutego 380 roku wydanego w Tesalonikach chrześcijaństwo wyznania nicejskiego stało się oficjalną religią Imperium Romanum; zabroniono w nim także wyznawania arianizmu oraz uprawiania kultów pogańskich ${ }^{34}$. Dokument Cuntos populos został uzupełniony i zaktualizowany przez późniejsze edykty

30 Por. H. Glaesener, Lempereur Gratien et S. Ambroise, „Revue d'Histoire et de Littérature Religieuse" 52 (1957), s. 466-488; D. Spychała, Cesarze rzymscy a arianizm..., dz. cyt., s. 70-71.

31 Codex Theodosianus 16, 5, dz. cyt., s. 856.

32 Por. M. Simonetti, La crisi ariana..., dz. cyt., s. 438-439.

33 Por. H. Chadwick, Priscillian of Avila: the occult and the charismatic in the early Church, Oxford 1975; A. Barzanò, Il cristianesimo nelle leggi..., dz. cyt., s. 73-74.

34 Codex Theodosianus 16, 1.2, dz. cyt.: „Imppp. Gratianus, Valentinianus et Theodosius aaa. edictum ad populum urbis Constantinopolitanae. Cunctos populos, quos clementiae nostrae regit temperamentum, in tali volumus religione versari, quam divinum petrum apostolum tradidisse Romanis religio usque ad nunc ab ipso insinuata declarat quamque pontificem Damasum sequi claret et Petrum Alexandriae episcopum virum apostolicae sanctitatis, hoc est, ut secundum apostolicam disciplinam evangelicamque doctrinam patris et filii et spiritus sancti unam deitatem sub parili maiestate et sub pia trinitate credamus. (380 febr. 27)". 
teodozjańskie z lat 391-392 35 . Za Teodozjusza I katolicyzm stał się więc oficjalną religią państwową, cesarz był katolikiem, a Kościół jako instytucja otrzymał szereg przywilejów państwowych oraz cesarskich gwarancji swobody wyznania. Ze swej strony Kościół uznał ówczesne cesarstwo rzymskie za własne środowisko socjalne uprzywilejowane i chciane przez Boga ${ }^{36}$. Jednocześnie Teodozjusz I chciał nadać Konstantynopolowi znaczenie odpowiednie do prowadzonej przez siebie polityki, co zdaniem Hugo Rahnera zmierzało do stworzenia nowego papiestwa, jakie miało powstać na Wschodzie, ale już pod protekcją cesarskąa ${ }^{37}$. Kościół na Zachodzie podkreślał natomiast swą niezależność wobec władzy cesarskiej ${ }^{38}$ oraz swój prymat jako sedes apostolica ${ }^{39}$. Tragiczne wydarzenia masakry w Tesalonikach z 390 roku stały się symbolicznym początkiem wschodniego cezaropapizmu ${ }^{40}$.

Wybór wyznania ariańskiego czy nicejskiego przez kolejnych cesarzy z dynastii konstantyjskiej i walentyniańskiej zależał od ich

35 Dekret cesarski z 24 lutego 391: Nemo se hostiis polluat (Codex Theodosianus 16, 10.10, dz. cyt.), znoszący kult pogański, zabraniający wchodzenia celem kultu do sanktuariów i do świątyń pogańskich oraz zakazujący oddawania czci posągom pogańskim; Dekret cesarski z 11 maja 391 (Codex Theodosianus 16, 7.4, dz. cyt.), ogłaszający kary administracyjne dla przechodzących z chrześcijaństwa na pogaństwo; Dekret cesarski z 16 czerwca 391 (Codex Theodosianus 16, 10.11, dz. cyt.), powtarzający zalecenia dekret z 24 lutego 391 roku, zabraniający ponownie kultu pogańskiego w świątyniach; Dekret cesarski z 8 listopada 392 roku, zwany Gentilicia constiterit superstitione Codex Theodosianus 16.10.12, dz. cyt.), zabraniający prywatnego kultu pogańskiego.

36 Por. N. King, Church-state relations, [w:] Early christianity. origins and evolution to ad 600, ed. I. Hazlett, London 1991, s. 251-253; C. Alzati, La Chiesa nell'Impero e l'imperatore nella Chiesa, [w:] L'impero romano-cristiano. Problemi politici, religiosi, culturali, ed. M. Sordi, Roma 1991, s. 206-210; D. Spychała, Cesarze rzymscy a arianizm..., dz. cyt., s. 71-73.

37 H. Rahner, Chiesa e struttura politica..., dz. cyt., s. 91; J. Rouge, La législation de Théodose contre les héretiqies. Traduction de C. Th. XVI, 5, 6-24, [w:] Epektasis, ed. J. Fontaine, Ch. Kannengiesser, Paris 1972, s. 635-649.

38 H. Rahner, Chiesa e struttura politica..., dz. cyt., s. 94.

39 M. Maccarrone, «Sedes apostolica - Vicarius Petri». La perpetuità del primato di Pietro nella sede e nel vescovo di Roma (secoli III-VIII), [w:] Il primato del vescovo di Roma nel primo millennio, ed. M. Maccarrone, Città del Vaticano 1991, s. 275-287.

40 H. J. Diesner, Kirche und Staat im ausgehenden vierten Jahrhundert: Ambrogio von Mailand, [w:] Das Frühe Christentum im Römischen Staat, ed. R. Klein, Darmstadt 1971, s. 415-454. 
osobistych przekonań religijnych. W stosunku do chrześcijaństwa cesarze IV wieku wykorzystywali swą godność pontifex maximus, skutkiem czego dokonała się jej stopniowa chrystianizacja. Ostatecznie decyzją cesarza Teodozjusza I katolicyzm w nicejskiej formie wyznania stał się oficjalną religią Imperium Romanum. Cesarz jako najwyższy przedstawiciel władzy świeckiej wyznawał wiarę katolicką, przekonany, że jego chrześcijańskie zaangażowanie zapewni mu sukces polityczny. Kościół katolicki ze swej strony, otrzymawszy państwowe przywileje prawne i ekonomiczne i cesarskie gwarancje zachowania swej uprzywilejowanej pozycji wobec kultów niekatolickich, uznał cesarstwo rzymskie za swój właściwy stan społeczno-polityczny chciany przez Boga i stał się Kościołem cesarskim.

\section{Arianizacja Gotów}

Jeśli można mówić o jakimś bezpośrednim wpływie kulturowo-społecznym arianizmu w IV wieku, to był nim niewątpliwie proces chrystianizacji, jaki dokonał się pośród Wizygotów. Ich germański świat posiadał własne tradycje kulturalne o charakterze narodowym i antyrzymskim. Chrystianizacja w formie ariańskiej wzmocniła wspomniane poczucie odrębności Gotów.

Konwersja przedstawicieli plemion germańskich na chrześcijaństwo dokonywała się na początku IV wieku, najczęściej podczas zaciągów do armii rzymskiej, dzięki kontaktom z chrześcijańskimi żołnierzami lub kupcami. Poza granicami Imperium Romanum częstą formą spotkania z chrześcijaństwem były uprowadzenia ludności chrześcijańskiej do niewoli ${ }^{41}$. Pośród germanskich foederati,

41 Pierwszym plemieniem germańskim, które weszło $\mathrm{w}$ proces chrystianizacji po 251 roku, byli prawdopodobnie Goci Cnivy, którzy uprowadzili w niewolę chrześcijańskich Rzymian; ci natomiast rozpoczęli ewangelizację swoich porywaczy. Wielu pojmanych przez Gotów w latach 50. III wieku Rzymian znalazło się na Półwyspie Tauryjskim (Krymskim). A. Kokowski (Goci. Od Skandzy do Campi Gothorum (od Skandynawii do Pótwyspu Iberyjskiego), Warszawa 2007, s. 275-276), analizując dzieje gockiego plemienia Tetraksytów (Trapezytów) podaje, powołując się na H. Wolframa (Die Goten. Von den Anfängen bis zur Mitte des sechsten Jahrhunderts, München 1990, s. 59-61), że imię tej grupy zostało nadane, kiedy w 256 roku splądrowali oni Trapezunt w Azji Mniejszej. Przyłączyło się wtedy do nich wielu tamtejszych niewolników, którzy byli chrześcijanami, co miało ogromny wpływ na fakt, że Goci krymscy 
osiedlonych na ziemiach cesarskich, nawrócenia na chrześcijaństwo nie były często spotykane. Pod koniec IV wieku rozprzestrzenianie się tej religii wśród plemion germańskich było bardzo ograniczone, nawet wśród Germanów będących w służbie rzymskiej ${ }^{42}$. Wyjątek stanowili Goci krymscy, zależni administracyjnie od biskupstwa konstantynopolitańskiego. Ich biskup Teofil („biskup kraju Gothia”) był uczestnikiem cesarskiego consilium w Nicei w 325 roku $^{43}$, a sama gmina pozostała pronicejska ${ }^{44}$.

Goci bałkańscy stali się natomiast arianami. Politycznie byli oni bardziej skłonni do chrystianizacji po klęsce, jaką zadały im wojska rzymskie pod wodzą cesarza Konstantyna II w kampanii w latach 331-334 ${ }^{45}$. Pierwsza chrystianizacja Gotów bałkańskich dokonała się dzięki działalności ariańskiego biskupa Wulfili (311-383). Jego ojcem był bogaty Got z klasy średniej, matką zaś chrześcijanka, uprowadzona z terenów Kapadocji. Wulfila po przyjęciu chrztu był lektorem, a w 341 roku, w wieku 30 lat, został wyświęcony na biskupa Gotów ${ }^{46}$. Głosił kazania w językach gockim, łacińskim i greckim.

przyjęli chrześcijaństwo w wersji ortodoksyjnej, a nie ariańskiej. Całą tę społeczność zaczęto też nazywać Trapezytami, co może oznaczać uchodźców z Trapezuntu.

42 A. Chauvot, Le migrazioni dei barbari e la loro conversione al Cristianesimo, [w:] Storia del Cristianesimo. Religione, politica, cultura, ed. Ch. e L. Pietri, vol. 2, La nascita di una cristianità (250-430), ed. ital. A. di Berardino, G. Alberigo, Roma 2000, s. 801-802.

43 Patrum Nicaenorum nomina, ed. H. Gelzer, H. Hilgenfeld, O. Cuntz, Lipsiae 1898, series latina $\mathrm{nr}$ 216, 219; series graeca $\mathrm{nr} 211$.

44 H. Wolfram, Historia Gotów, tłum. R. Darda-Staab, I. Dębek, K. Berger, WarszawaGdańsk 2003, s. 99-100.

45 Socrates Scholasticus, Historia ecclesiastica I, 18, 4, (PG 67, kol. 122.124); tłum. polskie: Sokrates Scholastyk, Historia Kościoła, tłum. S. J. Kazikowski, Warszawa 1986, s. 113: „Goci [...] po raz pierwszy uwierzyli w moc religii chrześcijańskiej, która ochroniła również Konstantyna".

46 Cesarz Konstantyn prawdopodobnie myślał o chrystianizacji Gotów, ale brakowało pośród nich duchownych; zapewne dlatego lektor Wulfila mógł być wyświęcony na biskupa z pominięciem diakonatu i prezbiteratu. Wulfila, według opinii Filostorgiusza z Borissos, por. Historia Ecclesiastica II, 5 (PG 65, kol. 468.469), miał być wyświęcony na biskupa w roku 332 przez bpa Euzebiusza z Nikomedii, kiedy to przybył do Konstantynopola z gockim poselstwem pokojowym. We wzmiance Filostorgiusza jest jednak wiele nieścisłości: Goci odwiedzili Konstantyna najpóźniej w roku 337; Euzebiusz z Nikomedii został biskupem Konstantynopola dopiero w 338 roku. Przyjąwszy zatem w miarę pewną liczbę 40 lat sprawowania urzędu biskupiego przez Wulfilę, współcześni historycy stoją na 
Wulfila prawdopodobnie stopniowo przechodził na arianizm, za którym ostatecznie opowiedział się na synodzie w Konstantynopolu w $360 \mathrm{roku}^{47}$.

„Apostoł Gotów” przyczynił się do arianizacji chrystianizowanej przez siebie populacji Gotów mezyjskich. Z analizy tekstów źródłowych, jaką przeprowadził Manlio Simonetti, wynika, że Wulfila był wyznawcą radykalnego arianizmu typu eunomiańskigo. Podpisanie przez niego w 360 roku w Konstantynopolu formuły wiary ${ }^{48}$, która koresponduje treściowo z ugodową formułą wiary z Rimini z 359 roku, zasugerowało niektórym badaczom wniosek, że Wulfilę należy identyfikować z arianami umiarkowanymi, tzw. homejczykami, twierdzą-

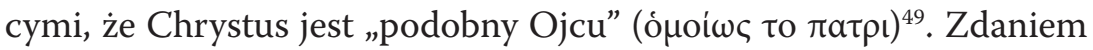
M. Simonettiego ${ }^{50}$ Wulfila początkowo oświadczał (por. List Ariusza

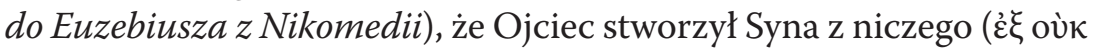
öv $\tau \omega v)^{51}$. Jednak z czasem biskup Gotów mezyjskich przyjął interpretację Eunomiusza, szczególnie jego wyjaśnienie tekstu Księgi Przysłów (Prz 8, 22-25), gdzie mówił o Bogu Ojcu jako stworzycielu Syna, używając czasownika „fecit” (nieobecnego w tekście Prz 8, 22-25), oraz czasowników pochodnych od „fecit”, tj. „genuit”, „creavit”, „fundavit". Wulfila, stosując powyższe terminy do określenia tzw. stworzenia Syna, wyraźnie opowiadał się za arianizmem radykalnym Eunomiusza i jego nazewnictwem dotyczącym stworzoności Chrystusa

stanowisku, że przyjął on święcenia biskupie w roku 341, na synodzie w Antiochii. Por. S. Longosz, Wulfila: propagator kultury chrześcijańskiej w starożytnej Mezji i Tracji, „Vox Patrum” 4 (1983), s. 125-159; P. Heather, Upadek cesarstwa rzymskiego, dz. cyt., s. 96-101.

47 Por. Sozomenos, Historia ecclesiastica 6, 37 (PG 65, kol. 1405); tłum. polskie: Historia Kościoła, tłum. S. Kazikowski, Warszawa 1980, s. 442.

48 Por. Sokrates Scholastyk, Historia Kościoła 2, 41, dz. cyt.; Sozomen, Historia Kościota 4, 24, dz. cyt.

49 Tak sądził np. K. F. Stroheker, zob. Germanentum und Spätantike, Zürich 1965, s. 170. Natomiast M. Meslin, Les Ariens d'Occident, 335-430, Paris 1967 (Patristica Sorbonensia, 8) zupełnie zignorował rolę Wulfili jako ariańskiego ewangelizatora Wizygotów, uznając za doktrynalnego leadera Gotów dopiero ok. 380 roku ariańskiego bpa Palladiusza z Ratiaria. Natomiast według H. E. Giesecke, Die Ostgermanen und der Arianismus, Berlin 1939, s. 28, Wulfila miał rozwinąć własną koncepcję chrystologiczną.

50 M. Simonetti, L'arianesimo di Ulfila..., dz. cyt., s. 304-305.

51 Por. Athanasius Werke, T. III, Teil 1, Urkunden zur Geschichte des arianischen Streites 318-328, ed. H. G. Opitz, Berlin-Leipzig 1934-1935, s. 3. 
$(\kappa \tau i \sigma \mu \alpha, \pi o i ́ \eta \mu \alpha)^{52}$. Syn według Wulfili jest całkowicie zależy od Ojca („post Patrem”), który Go definiuje i przyznaje Mu określone atrybuty, spośród których najważniejszym byłoby „dominus et rex”; określa Go także słowem „Deus” (nie dzięki naturze, a przez adopcję i usynowienie $)^{53}$. Wulfila konsekwentnie twierdził, że Ojciec stworzył Syna, a Syn stworzył wszechświat. Dlatego Ojciec jest Bogiem dla Syna, a Syn jest Bogiem dla stworzenia ${ }^{54}$. W związku z powyższym M. Simonetti zasadnie konkluduje, że Wulfila nie był ani arianinem umiarkowanym, ani arianinem sui generis, ale arianinem radykalnym, wiernym doktrynie Eunomiusza ${ }^{55}$.

W roku 347 lub 348 miało miejsce prześladowanie ariańskich Gotów, którego inicjatorem był wódz Atanaryk ${ }^{56}$. Męczennikami z tego okresu byli prawdopodobnie Inna, Rima i Pina ${ }^{57}$. W obliczu prześladowań Wulfila i goccy chrześcijanie poprosili cesarza Walensa o zgodę na osiedlenie się na terenie cesarstwa w Dolnej Mezji (Moesia Inferior) koło Nikopolis. Z czasem Wulfila został biskupem myzyjskiego Nikopolis, odpowiedzialnym również za ewangelizację obszarów wiejskich ${ }^{58}$. Goci bałkańscy zetknęli się z chrześcijaństwem wyłącznie w wersji ariańskiej, przekazanej im przez Wulfilę ${ }^{59}$. Goci

52 Por. Wyznanie wiary Ariusza wysłane Aleksandrowi, biskupowi Aleksandrii, [w:] $U r$ kunden zur Geschichte des arianischen Streites..., dz. cyt., s. 13 i Eunomiusz, Apologia (PG 30, kol. 844-845 (9), kol. 846-847 (11), kol. 847 (12), kol. 850-851 (15), kol. 867 (28)); M. Simonetti, L'arianesimo di Ulfila..., dz. cyt., s. 305.

53 Por. Urkunden zur Geschichte des arianischen Streites..., s. 3; M. Simonetti, Larianesimo di Ulfila..., dz. cyt., s. 306.

54 M. Simonetti, L'arianesimo di Ulfila..., dz. cyt., s. 311.

55 M. Simonetti, L'arianesimo di Ulfila..., dz. cyt., s. 322-323. Por. wyznanie wiary Wulfili w: Auxentius Durostorensis, Epistola de fide, vita et obitu Wulfilae 63 (Patrologia Latina, ed. J. P. Migne, Suppl. I, Paris 1958, kol. 707); tłum. polskie J. M. Szymusiak, Breviarium fidei, Poznań 1964, s. 196-197, „[...] Wierzę, że jeden jest Bóg Ojciec, jedyny niezrodzony i niewidoczny; [wierzę] także w jednorodzonego Syna Jego, Pana naszego i Boga, Stwórcę, który daje byt wszelkiemu stworzeniu i nie znajduje równego sobie. A więc jeden jest Bóg Ojciec, który jest Bogiem wszystkich, nawet naszego Boga [...] [Wierzę] w Syna poddanego i we wszystkim posłusznego Bogu Ojcu, któremu jest podobny według Pisma św. [...]".

56 Auxentius Durostorensis, Epistola de fide, vita et obitu Wulfilae 58, dz. cyt., kol. 706.

57 Passio ss. Innae, Rimae et Pinae, ed. H. Delehaye, Saints de Thrace et de Mésie, „Analecta Bollandiana" 31 (1912), s. 215-216.

58 Por. Auxentius Durostorensis, Epistola de fide, vita et obitu Wulfilae 46, dz. cyt., kol. 704.

59 M. Wilczyński, Germanie w stużbie zachodniorzymskiej w V w. n.e., Kraków 2001, s. 83. 
mezyjscy, już jako arianie, dali początek misji wewnątrzgermańskiej i przekazali chrześcijaństwo $\mathrm{w}$ formie ariańskiej Ostrogotom już na ziemiach naddunajskich ${ }^{60}$. Jednak większość Germanów nacierających na prowincje Cesarstwa zachodniorzymskiego na przełomie IV i V wieku pozostała pogańska ${ }^{61}$. Według Knuta Schaeferdieka i Petera Heathera masowe nawrócenie Wizygotów dokonywało się zarówno w latach 373-375, jak i w 376 roku (w wyniku działań gockiego wodza Fritigerna, kontaktującego się z cesarzem Walensem, od którego uzyskał poparcie w zamian za przejście na arianizm, dlatego walczył z nastawionym antyrzymsko i antychrześcijańsko wodzem Atanarykiem $)^{62}$. Natomiast Edward A. Thompson sądzi, że masowe przejście Gotów na arianizm dokonało się najprawdopodobniej po 382 roku, kiedy cesarz Teodozjusz pozwolił im na osiedlenie się w Tracji ${ }^{63}$.

Wulfila rozwijał też działalność literacką. Najistotniejszym jego dziełem był przekład Biblii na język gocki, którym prawdopodobnie mówili zarówno Goci, jak i Gepidzi czy Wandalowie ${ }^{64}$. Wulfila wynalazł i rozpowszechnił gocki alfabet (na bazie greki, alfabetu łacińskiego i pisma runicznego). Utworzenie gockiego alfabetu, przekład Biblii oraz stworzenie liturgii ariańskiej w języku gockim przy zastosowaniu właściwej mu wersyfikacji i melodyki były czynnikami utrwalenia gockiej tożsamości ${ }^{65}$.

Jak zauważa Bruno Luiselli, w rozwoju języka gockiego w fazie „przedwulfiańskiej” istniały już liczne grecyzmy i latynizmy chrze-

60 P. Scardigli, La conversione dei Goti al Cristianesimo, „Settimane di Studio del Centro Italiano di Studi sull'Alto Medioevo" 14 (1967), s. 47-86.

61 M. Mączyńska, Wędrówki ludów. Historia niespokojnej epoki IVi V wieku, Warszawa-Kraków 1996, s. 36-37.

62 K. Schaeferdiek, Die Kirche des früheren Mittelalters, [w:] Kirchengeschichte als Missiongeschichte, vol. II, hg. von K. Schaeferdiek, München 1978, s. 79-90 (konwersja Gotów miałaby dokonać się w latach 373-375 i w roku 376); P. Heather, The crossing of the danube and the Gothic conversion, "Greek, Roman and Byzantine Studies” 27 (1986), s. 289-318 (konwersja Gotów miała nastąpić w 376 roku).

63 E. A. Thompson, The date of the conversion of the Visigoths, "Journal of Ecclesiastical History" 7 (1956), s. 1-11; E. A. Thompson, Visigoths, in the time of Ulfila, Oxford 1966.

64 Procopius Caesariensis, De bello Vandalico 1.2. 1-5, ed. G. Niebuhri, Bonn 1833, s. 312-313 (Corpus Scriptorum Historiae Byzantinae [dalej: CSHB], 1); Por. K. Schaeferdiek, Germanenmission, [w:] Reallexikon für Antike und Christentum [dalej: RACh], t. 10, ed. T. Klauser, Stuttgart 1978, s. 492-548; S. Longosz, Wulfila: propagator kultury chrześcijańskiej w starożytnej Mezji i Tracji..., dz. cyt., s. 148-159.

65 H. Wolfram, Historia Gotów, dz. cyt., s. 102. 
ścijańskie, opisujące konkretne desygnaty: np. aggilus $\leftarrow$,angelus", aikklesjo $\leftarrow$ „ecclesia", aipiskaupus $\leftarrow$,episkopus", aipistula $\leftarrow$ „epistula", aiwaggeljo $\leftarrow$ "evangelium”, apaustaulus $\leftarrow$ "apostolus”, daimonareis $\leftarrow$ "indemoniatus", diabaulus $\leftarrow$ "diabolus", diakaunus $\leftarrow$ „diaconus", praufetes $\leftarrow$ „profetus". Zacytowane kalki semantyczne z chrześcijańskiego słownictwa dołączyły zatem do innych zapożyczeń z języka łacińskiego czy greckiego, jakie przeniknęły do słownictwa gockiego $\mathrm{w}$ okresie ich osadnictwa nadwiślańskiego (tzw. okres kultury wielbardzkiej) ${ }^{66}$.

Zdaniem tego samego badacza w wyniku chrystianizacji na przełomie III i IV wieku przeniknęły do języka gockiego podstawowe koncepcje chrześcijańskie o wierze, uwierzeniu, zbawieniu, łasce i usprawiedliwieniu, miłości jako agape czy ciele jako elemencie przemijającego świata. Jednak w ewangelizacji Gotów, czyli ludu niebędącego ani narodem greckojęzycznym, ani łacińskojęzycznym, chrześcijańska terminologia tych języków okazała się całkowicie niedostosowana do wyrażenia wymienionych koncepcje. Dlatego aby wypowiedzieć $\mathrm{w}$ języku gockim te niełatwe znaczenia teologiczne, zostały zastosowane słowa pochodzące z jego narodowej leksyki, np.:

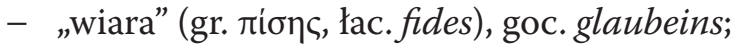

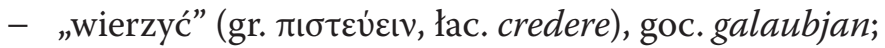

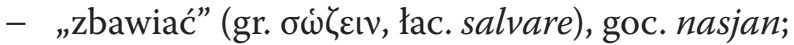

- „Zbawiciel” (gr. $\Sigma \omega \tau$ ๆ́ $\rho$, łac. Salvator), goc. Nasjands;

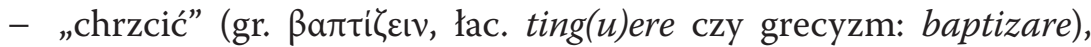
goc. daupjan;

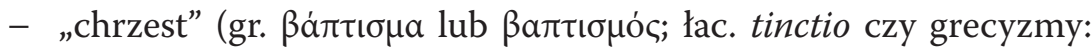
baptisma, baptismus), goc. daupeins;

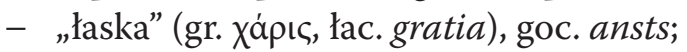

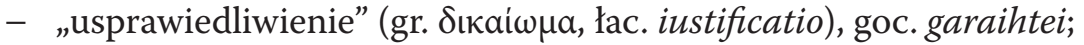

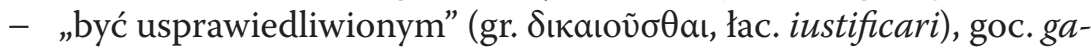
raihts wairdan;

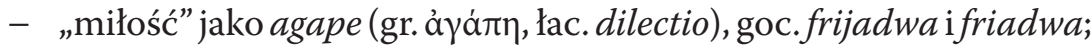

- „ciało” jako światowość lub świeckość (gr. $\sigma \alpha ́ \rho \xi$, łac. caro), goc. leik. Bruno Luiselli stwierdza, że nie posiadamy dziś udokumentowanego materiału językowego dla języka gockiego sprzed tłumaczenia Biblii przez Wulfilę, dlatego nie możemy dokładnie porównywać

66 B. Luiselli, La formazione della cultura europea occidentale..., dz. cyt., s. 125-126. 
znaczeń pogańskich i chrześcijańskich dla wymienionych wyrażeń. Możemy jednak przypuszczać, że wymienione terminy w języku gockim, tak typowe dla chrześcijaństwa, stanowią konkretny efekt chrystianizacji tego języka i nadania zwyczajnym jego wyrażeniom konotacji chrześcijańskiej ${ }^{67}$. W języku gockim występują też ewidentne kalki semantyczne chrześcijańskich terminów łacińskich czy greckich, np.:

- goc. armahairts („miłosierny”), utworzone od łac. misericors i goc. arma (<goc. arms $\rightarrow$ łac. misero), odpowiadające łac. miseri-i goc. -hairts (<hairto $\rightarrow$ cor $)$;

- goc. mipwissei („poznanie”), utworzone albo od łac. conscientia, albo od grec. $\sigma u v \varepsilon i \delta \oint \eta \iota \varsigma$, goc. mip odpowiada albo łac. cum- albo grec. ovv-, oraz goc. -wissei („wiedzieć”) odpowiadające łac. scientia lub grec. eĩov;

- goc. gudhus („świątynia”), utworzone od łac. domus dei, składa się z goc. gud („bóg”), odpowiadającego łac. deus, oraz z goc. hus („dom”), odpowiadającego łac. domus;

- goc. usstass („zmartwychwstanie”), utworzone prawdopodobnie

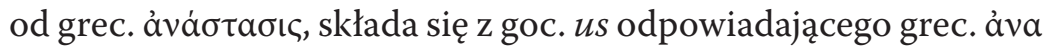

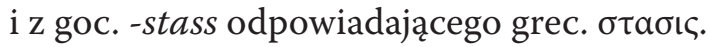

Luiselli zauważa, że gocki chrześcijański, stosujący latynizmy i grecyzmy będące semantycznymi neologizmami czy też zupełnie nowymi formacjami leksykalnymi, wskazuje na proces uformowania się w IV wieku wewnątrz pierwotnego języka gockiego specyficznego i właściwego języka chrześcijańskiego ${ }^{68}$. Podobne procesy językowe w obrębie języka greckiego czy łacińskiego w I wieku zaobserwowali przedstawiciele słynnej szkoły z Nijmegen - Jozef Karl Frans Hubert Schrijnen (1869-1938) ${ }^{69}$ i Christine Mohrmann (1903-1988) ${ }^{70}$.

Jednym z najciekawszych przekładów terminów chrześcijańskich dokonanych przez Wulfilę na język gocki jest tłumaczenie terminu

67 Por. B. Luiselli, La formazione della cultura europea occidentale..., dz. cyt., s. 126-127.

68 Por. B. Luiselli, La formazione della cultura europea occidentale..., dz. cyt., s. 128.

${ }^{69}$ Por. J. K. F. H. Schrijnen, Charakteristik des altchristlichen Latein, Nijmegen 1932 (Latinitas Christianorum Primaeva, 1).

70 Por. Ch. Mohrmann, Die altchristliche Sondersprache in den Sermones des heiligen Augustin, Nijmegen 1932 (Latinitas Christianorum Primaeva, 3); Ch. Mohrmann, Latin Vulgaire, Latin des Chrétiens, Latin Médiéval, Paris 1955; Ch. Mohrmann, Études sur le latin des chrétiens, Roma 1958'; Roma 1961-1977², 4 voll. 
„Duch Święty”. Gockie określenia Atta („Ojciec”, grec. Пaтńp, łac. Pater) i Sunus („Syn”, grec. Yióc, łac. Filius) odpowiadają chrześcijańskim terminom greckim czy łacińskim. Natomiast gockie Ahma („Duch”) nie odpowiada ani greckiemu Пvعṽ $\alpha$, ani łacińskiemu Spiritus. Te ostatnie wywodzą swe znaczenie od pojęcia „tchnienie”, „wiatr”. Natomiast gockie Ahma pochodzi od rdzenia czasownikowego "ah-, oznaczającego „myślenie” (goc. aha, „myślenie”, „rozum”; goc. ahjan, „myśleć") i oznacza Byt myślący. Stąd natchnienie będące dziełem Ducha Świętego to w języku gockim ahmateins. Wulfila znał gocki termin waian oznaczający „tchnienie” (od „wiatr”), lecz nie użył go do utworzenia w gockim terminu „Duch”. Dlaczego? Według B. Luiselliego pogańscy Goci czcili swe bóstwa w świętych gajach (por. np. Tacyt, Germania 9, 2) i szukali potwierdzenia swych decyzji w znakach pochodzących ze świętych gajów (Klaudian, De bello Gothico, v. 545548). Ową odpowiedzią bóstw ze świętych gajów był najczęściej znak poszumu liści poruszanych powiewem wiatru. Wulfila, znając ową obyczajowość religijną pogańskich Gotów, tworząc język chrześcijański chciał prawdopodobnie uniknąć konotacji Ducha Świętego z germańską religijnością odczytującą w powiewie wiatru w świętych gajach gockich znak dany od bóstwa. Dlatego w swoim przekładzie Biblii na język gocki wywiódł znaczenie Ducha Świętego od czynności myślenia, które było w jego przekonaniu wybranym procesem Jego działania i interwencji. Ta innowacja w tłumaczeniu znaczenia słowa „Duch” w języku gockim była przeznaczona bardziej użytek zwykłych Gotów, gdyż tamtejsze duchowieństwo było raczej zdolne odnaleźć różnicę pomiędzy tchnieniem jako zjawiskiem naturalnym a tchnieniem rozumianym jako działanie Ducha. Zdaniem B. Luiselliego takie pojmowanie Ducha Świętego przez Wulfilę znajduje potwierdzenie w świadectwie ucznia „Apostoła Gotów” - ariańskiego biskupa Auksencjusza z Durostorum ${ }^{71}$. W wyznawanym przez niego credo nie odnosił on do Ducha Świętego pojęć związanych z tchnieniem, ale określał Go kategoriami związanymi z poznawaniem, jak: inluminator, sanctificator, doctor, ducator, adiutor, postulator, informator, virtus inluminans, virtus sanctificans ${ }^{72}$.

71 Por. B. Luiselli, La formazione della cultura europea occidentale..., dz. cyt., s. 129-130.

72 Por. Auxentius Durostorensis, Epistola de fide, vita et obitu Wulfilae 51, dz. cyt., s. 705; Auxentius Durostorensis, Epistola de fide vita et obitu Wulfilae 63, dz. cyt., 707; Auxentius Durostorensis, Scripta Arriana Latina, pars 1, Collectio Veronensis. 
Arianizm rozprzestrzenił się w IV wieku najpierw pośród Wizygotów, następnie pośród Gepidów, Wandalów i Ostrogotów, czyli plemion germańskich obecnych we wschodnich i w północno-wschodnich prowincjach Imperium Romanum. Wszystkie te narody zachowywały chrześcijaństwo w formie ariańskiej jeszcze przez co najmniej dwa wieki. Chrystianizacja wewnątrzgermańska była w IV wieku przede wszystkim ariańska. Wynikało to z kilku powodów. Po pierwsze najważniejszy Apostoł Gotów, Wulfila, przeszedł na arianizm radykalny. Po drugie arianizacja Gotów i innych plemion germańskich odbywała się dzięki czynnikom utrwalenia gockiej czy też germańskiej tożsamości (utworzeniu gockiego alfabetu, przekład na gocki Biblii, przepowiadanie w języku gockim, stworzeniu liturgii ariańskiej w języku gockim). Wyznanie ariańskie stało się zatem zasadą tożsamości germańskiej wobec katolickiego Imperium Romanum.

\section{Podsumowanie}

Od 324 roku Konstantyn zaczął otwarcie uchwalać prawa prochrześcijańskie celem utworzenia warunków do pokojowego współistnienia państwa i Kościoła. Cesarskie consilium z 325 roku, zwołane dla uczczenia jubileuszu dwudziestolecia rządów Konstantyna Wielkiego, miało stać się również okazją do uroczystego ogłoszenia przez cesarza pojednania wszystkich zwaśnionych stron. Strony sporów teologicznych jednak się nie pojednały, natomiast cesarz politycznie uwiarygodnił kościelne pozbawienie urzędów i wykluczenie ze stanu duchownego zwolenników Ariusza. Praktyka politycznego wymuszania na biskupach podzielania określonej opinii teologicznej, tj. tej uznawanej przez władcę, stała się normą w cesarstwie po 325 roku. Konstantyńska idea, że cesarz jest najwyższym pontyfikiem oraz „biskupem rzeczy zewnętrznych", była podzielana przez większość jego następców. Konsekwencją praktyczną wprowadzenia tych zasad było

Scholia in concilium Aquileiense. Fragmenta in Lucam rescripta. Fragmenta theologica rescripta, ed. R. Gryson, Turnhout 1982, s. 160-166 (Corpus Christianorum. Series Latina, 87). 
strzeżenie przez cesarzy porządku religijnego w cesarstwie. W zależności od sympatii teologicznej władcy raz było preferowane chrześcijaństwo pronicejskie, a innym razem ariańskie. O rodzaju wiary, wokół której miała się kształtować jedności religijna cesarstwa, decydował wybór danego władcy. Ostatecznie mocą decyzji Teodozjusza Wielkiego cesarstwo miało osiągnąć jedność religijną w oparciu o chrześcijaństwo wyznające wiarę nicejską. Kościół zaś, uprzywilejowany przez państwo, stał się pod koniec IV wieku Kościołem cesarskim.

W wyniku ariańskiej chrystianizacji Wizygotów w IV wieku zostały wzmocnione ich własne tradycje kulturowe. Stworzenie przez Wulfilę gockiego alfabetu umożliwiło mu przekład Biblii oraz stworzenie liturgii ariańskiej w języku gockim przy zastosowaniu wersyfikacji i melodyki gockiej. Były to czynniki kulturowe utrwalające tożsamość, szczególnie zaś wzmacniające gocki nacjonalizm oraz antyrzymskość. Językiem gockim mówiły (oprócz plemion Wizygotów) także plemiona Gepidów, Ostrogotów i Wandalów. Wewnętrzna misja chrystianizacyjna, jaka zaczęła dokonywać się od IV wieku pośród tych plemion właśnie w języku gockim, propagując chrześcijaństwo w formie ariańskiej, wzmacniała także ich odrębność. W V wieku określenie „arianin” oznaczało dla Rzymian przynależność do któregoś z plemion germańskich. Arianizm wyrażony w języku gockim stał się zatem nośnikiem germańskiej tożsamości.

\section{Summary}

\section{The political and cultural consequences of Arian controversy in the $4^{\text {th }}$ century}

Constantinian and Valenitinians Dynasties took over the role of a patron for the Christianity and supported the Church financially and politically. It resulted in their intervention in the affairs of the Church especially in the theological dispute during the Arian controversy. Constantine the Great frequently used force to push the proper (ie. of his own) theological opinion. After the Council of Nicea every Church decision or the bishops' theological opinion was limited by a political supremacy. Constantine eventually became a "main pontifex" and a „bishop of external matters”. His successors have gone the same way. Emperors according to their doctrinal preferences supported the Nicean Christianity or Arianism. The doctrine confessed by the emperor became a state's official doctrine. 
The Visigoths adopted the Arian version of Christianity in the IV th. By midforth century they had a Bible in their own language. Bishop Ulfias (Wulfila) translated the Greek Bible into the Gothic language. For this he devised the gothic alphabet. He elaborated also a liturgy in gothic language according Arians doctrine. It was a solid footing for their Gothic cultural and national identity and anti- Roman opposition in consequence. Besides Visigoths the Gothic language was spoken by other Germanic tribes such as Gepids, Ostrogoths and Vandals. In the fifth century the label: Arian stood for any member of German tribe. Arianism in its gothic version became a mean of the German identity.

Keywords: Arian controversy, IV century, political and cultural consequences

\section{Bibliografia}

Alzati C., La Chiesa nell'Impero e l'imperatore nella Chiesa, [w:] L'impero romano-cristiano. Problemi politici, religiosi, culturali, ed. M. Sordi, Roma 1991, s. 206-210.

Athanasius Werke, T. III, Teil 1, Urkunden zur Geschichte des arianischen Streites, ed. H. G. Opitz, Berlin-Leipzig 1934-1935.

Auxentius Durostorensis, Epistola de fide, vita et obitu Wulfilae (Patrologia Latina, ed. J. P. Migne, Suppl. I, Paris 1958, kol. 703-707); tłum. polskie: J. M. Szymusiak, Breviarium fidei, Poznań 1964, s. 196-197.

Auxentius Durostorensis, Scripta Arriana Latina, pars 1, Collectio Veronensis. Scholia in concilium Aquileiense. Fragmenta in Lucam rescripta. Fragmenta theologica rescripta, ed. R. Gryson, Turnhout 1982, s. 160-166 (Corpus Christianorum. Series Latina, 87).

Baldini A., Il dibattito contemporaneo sulla conversione di Costantino, „Salesianum” 67 (2005), s. 701-735.

Barzanò A., Il Cristianesimo nelle leggi di Roma Imperiale, Milano 1996.

Baus K., Il divenire della Chiesa imperiale nell'ambito della politica religiosa dell'Impero, [w:] Storia della Chiesa, vol. II, red. H. Jedin, Milano 1983, s. 89-92.

Berardino di, A., Limperatore Costantino e la celebrazione della Pasqua, [w:] G. Bonamente, F. Fusco, Costantino il Grande dall'antichità all'umanesimo, t. 1, Macerata 1992, s. 363-384.

Biondi B., Il diritto romano cristiano, vol. I, Orientamento religioso della legislazione, Milano 1952.

Bonamente G., La „svolta costantiniana”, [w:] Chiesa e impero. Da Augusto a Giustiniano, ed. E. Dal Covolo, R. Uglione, Roma 2001, s. 145-170 (Biblioteca di Scienze Religiose, 170). 
Bralewski S., Cesarz Konstantyn I Wielki wobec kontrowersji ariańskiej, Poznań 2009.

Ceran W., Konstancjusz II, [w:] Encyklopedia kultury bizantyńskiej, red. O. Jurewicz, Warszawa 2002, s. 269-270.

Ceran W., Kościót wobec antychrześcijańskiej polityki cesarza Juliana Apostaty, Łódź 1980 (Acta Universitatis Lodziensis. Seria I, Nauki Humanistyczno-Społeczne. Folia Historica, 63).

Chadwick H., Priscillian of Avila: the occult and the charismatic in the early Church, Oxford 1975.

Chauvot A., Le migrazioni dei barbari e la loro conversione al Cristianesimo, [w:] Storia del Cristianesimo. Religione, politica, cultura, ed. Ch. e L. Pietri, vol. 2, La nascita di una cristianità (250-430), ed. ital. A. di Berardino, G. Alberigo, Roma 2000, s. 801-802.

Codex Theodosianus, ed. P. Krueger, T. Mommsen, Berlin 1905.

Constitutionibus Sirmondianis, ed. P. Krueger, Th. Mommsen, Berlin 1905.

Crook J., Consilium principis, imperial councils and counsellors from Augustus to Diocletian, New York 1975.

Dal Covolo E., Il "capovolgimento" dei rapporti tra la Chiesa e l'impero, [w:] Chiesa e impero. Da Augusto a Giustiniano, ed. E. Dal Covolo, R. Uglione, Roma 2001, s. 199-208 (Biblioteca di Scienze Religiose, 170).

De Giovanni L., Il Libro XVI del Codice Teodosiano. Alle origini della codificazione in tema di rapporti Chiesa-Stato, Napoli 1985.

Diesner H. J., Kirche und Staat im ausgehenden vierten Jahrhundert: Ambrogio von Mailand, [w:] Das Frühe Christentum im Römischen Staat, ed. R. Klein, Darmstadt 1971, s. 415-454.

Dokumenty synodów od 50 do 381 roku, red. A. Baron, H. Pietras, Kraków 2006 (Źródła Myśli Teologicznej, 37).

Dumézil B., Chrześcijańskie korzenie Europy. Konwersja i wolność w królestwach barbarzyńskich od V do VIII wieku, tłum. P. Rak, Kęty 2008.

Eunomiusz, Apologia (Patrologia Graeca, ed. J. P. Migne, Paris 1857-1866, t. 30, kol. 835-868).

Euzebiusz z Cezarei, Historia ecclesiastica, red. E. Schwartz, T. Mommsen, Berlin 1908 (Die Griechischen Christlichen Schriftsteller, 9/2).

Euzebiusz z Cezarei, Życie Konstantyna, wstęp, tłum., przypisy T. Wnętrzak, Kraków 2007 (Źródła Myśli Teologicznej, 44).

Evangelizzazione delloccidente dal III all'VIII secolo. Lingua e linguaggi. Dibattito teologico. Saggi racolti ed editi, red. I. Mazzini i L. Bacci, Roma 2001 (Biblioteca di Cultura Romanobarbarica, 5). 
Farina R., Limpero e l'imperatore cristiano in Eusebio di Cesarea. La prima teologia politica del cristianesimo, Zürich 1966, s. 236-248 (Biblioteca Teologica Salesiana. Fontes, 2).

Filostorgiusz z Borissos, Historia Ecclesiastica (Patrologia Graeca, ed. J. P. Migne, Paris 1857-1866, t. 65).

Fonti per la storia della cristianizzazione dei Germani (secoli III-VIII), red. B. Luiselli et al., Roma 2007 (Biblioteca di Cultura Romanobarbarica, 9).

Gaudemet J., L'Église dans l'Empire Romain (IV-V siècles), Paris 1958.

Gemmiti D., La Chiesa privilegiata nel Codice Teodosiano. Vescovo, clero e monaci: aspetti emblematici, Napoli-Roma 1991.

Giesecke H. E., Die Ostgermanen und der Arianismus, Berlin 1939.

Glaesener H., L'empereur Gratien et S. Ambroise, „Revue d'Histoire et de Littérature Religieuse" 52 (1957), s. 466-488.

Gliściński J., Wspótistotny Ojcu, Łódź 1992.

Heather P., The crossing of the danube and the Gothic conversion, „Greek, Roman and Byzantine Studies" 27 (1986), s. 289-318.

Heather P., Upadek Cesarstwa Rzymskiego, tłum. J. Szczepański, Poznań 2006.

Jones H. M., The later Roman Empire. 284-602. A social economic and administrative survey, vol. II, ed. B. Blackwell, Oxford 1964.

Kasprzak D., Konwersja na chrześcijaństwo plemion germańskich od IV do IX wieku, „Roczniki Historii Kościoła” 2/57 (2010), s. 19-55.

King N., Church-state relations, [w:] Early christianity. origins and evolution to ad 600, ed. I. Hazlett, London 1991, s. 251-253.

Kokowski A., Goci. Od Skandzy do Campi Gothorum (od Skandynawii do Pótwyspu Iberyjskiego), Warszawa 2007.

Longosz S., Wulfila: propagator kultury chrześcijańskiej w starożytnej Mezji i Tracji, „Vox Patrum” 4 (1983), s. 125-159;

Luiselli B., La formazione della cultura europea occidentale, Roma 2003.

Maccarrone M., «Sedes apostolica - Vicarius Petri». La perpetuità del primato di Pietro nella sede e nel vescovo di Roma (secoli III-VIII), [w:] Il primato del vescovo di Roma nel primo millennio, ed. M. Maccarrone, Città del Vaticano 1991, s. $275-287$.

Mazzarino S., L'Impero romano, vol. II, Roma-Bari 1996.

Mączyńska M., Wędrówki ludów. Historia niespokojnej epoki IV $i$ V wieku, Warszawa-Kraków 1996.

Meslin M., Les Ariens d'Occident, 335-430, Paris 1967 (Patristica Sorbonensia, 8).

Mohrmann Ch., Die altchristliche Sondersprache in den Sermones des heiligen Augustin, Nijmegen 1932 (Latinitas Christianorum Primaeva, 3).

Mohrmann Ch, Études sur le latin des chrétiens, Roma 1958-1977, 4. voll. 
Mohrmann Ch, Latin Vulgaire, Latin des Chrétiens, Latin Médiéval, Paris 1955.

Olszaniec S., Julian Apostata jako reformator religijny, Kraków 1999.

Passio ss. Innae, Rimae et Pinae, ed. H. Delehaye, Saints de Thrace et de Mésie, „Analecta Bollandiana" 31 (1912), s. 215-216.

Patrum Nicaenorum nomina, ed. H. Gelzer, H. Hilgenfeld, O. Cuntz, Lipsiae 1898.

Pavan M., Sant'Ambrogio e il problema dei barbari, „Romanobarbarica” 3 (1978), s. $167-187$.

Pietras H., Sobór nicejski (325). Kontekst religijny i polityczny, dokumenty, komentarze, Kraków 2013.

Procopius Caesariensis, De bello Vandalico, ed. G. Niebuhri, Bonn 1833 (Corpus Scriptorum Historiae Byzantinae, 1).

Rahner H., Chiesa e struttura politica nel cristianesimo primitivo, Milano 1990.

Rémondon R., La crisi dell'Impero Romano. Da Marco Aurelio ad Anastasio, Milano 1975.

Rouge J., La législation de Théodose contre les héretiqies. Traduction de C. Th. XVI, 5, 6-24, [w:] Epektasis, ed. J. Fontaine, Ch. Kannengiesser, Paris 1972, s. 635-649.

Rufin z Akwilei, Historia ecclesiastica, ed. M. Simonetti, Aquileia 2000 (Scrittori della Chesa di Aquileia, V/20).

Scardigli B., Scardigli P., I rapporti fra Goti e Romani nel III e IV secolo, „Romanobarbarica" 1 (1976), s. 260-295.

Scardigli P., La conversione dei Goti al Cristianesimo, „Settimane di Studio del Centro Italiano di Studi sull'Alto Medioevo" 14 (1967), s. 47-86.

Schaeferdiek K., Die Kirche des früheren Mittelalters, [w:] Kirchengeschichte als Missiongeschichte, vol. II, hg. von K. Schaeferdiek, München 1978, s. 79-90.

Schaeferdiek K., Germanenmission, [w:] Reallexikon für Antike und Christentum, t. 10, ed. T. Klauser, Stuttgart 1978, s. 492-548.

Schatz K., Sobory powszechne. Punkty zwrotne w historii Kościoła, tłum. J. Zakrzewski, Kraków 2001.

Schrijnen J. K. F. H., Charakteristik des altchristlichen Latein, Nijmegen 1932 (Latinitas Christianorum Primaeva, 1).

Setton K. M., Christian attitude towards the Emperor in the fourth century especially as shown in addresses to the Emperor, New York 1967 (Studies in History, Economics and Public Law, 482).

Simonetti M., L'arianesimo di Ulfila, „Romanobarbarica” 1 (1976), s. 297-323.

Simonetti M., La crisi ariana nel IV secolo, Roma 1975.

Socrates Scholasticus, Historia ecclesiastica (Patrologia Graeca, ed. J. P. Migne, Paris 1857-1866, t. 67); tłum. polskie: Sokrates Scholastyk, Historia Kościoła, tłum. S. J. Kazikowski, Warszawa 1986. 
Sozomen, Historia ecclesiastica, ed. J. Bidez, G. Ch. Hansen, Berlin 1960 (Die Griechischen Christlichen Schriftsteller, 50).

Sozomenos, Historia ecclesiastica (Patrologia Graeca, ed. J. P. Migne, Paris 18571866, t. 65); tłum. polskie: Sozomen, Historia Kościoła, tłum. S. Kazikowski, Warszawa 1980.

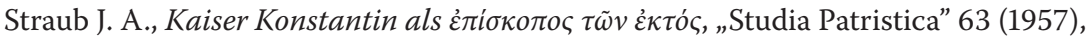
s. $678-695$.

Stroheker K. F., Germanentum und Spätantike, Zürich 1965.

Spychała D., Cesarze rzymscy a arianizm: od Konstantyna Wielkiego do Teodozjusza Wielkiego (312-395), Poznań 2007.

Thompson E. A., The date of the conversion of the Visigoths, „Journal of Ecclesiastical History" 7 (1956), s. 1-11.

Thompson E. A., Visigoths, in the time of Ulfila, Oxford 1966.

Università degli Studi di Firenze. Seminario di Filologia Germanica, Studi sulla civiltà dei Goti, Firenze 1971.

Wilczyński M., Germanie w stużbie zachodniorzymskiej w Vw. n. e., Kraków 2001.

Wolfram H., Die Goten. Von den Anfängen bis zur Mitte des sechsten Jahrhunderts, München 1990.

Wolfram H., Historia Gotów, tłum. R. Darda-Staab, I. Dębek, K. Berger, WarszawaGdańsk 2003. 